\title{
15. MINERALOGICAL STUDY OF UPPER MIOCENE SEDIMENTS FROM WIRELINE LOGS AND CORE MEASUREMENTS, SITE 652, OCEAN DRILLING PROGRAM LEG 107 (TYRRHENIAN SEA)1
}

\author{
Cristina Broglia, ${ }^{2}$ B. Charlotte Schreiber, ${ }^{3}$ Maria Bianca Cita, ${ }^{4}$ Hervè Chamley, ${ }^{5}$ and Roy Dove ${ }^{6}$
}

\begin{abstract}
The upper Miocene sedimentary sequence of Site 652, located on the lower continental margin of eastern Sardinia, was cored and logged during Ocean Drilling Program (ODP) Leg 107. Geophysical and geochemical logs from the interval $170-365 \mathrm{~m}$ below seafloor (mbsf), as well as various core measurements ( $\mathrm{CaCO}_{3}$, grain size, X-ray diffraction), provide a mineralogical-geochemical picture that is interpreted in the framework of the climatic and tectonic evolution of the western Tyrrhenian.

The results indicate the presence of short- and long-term mineralogical variations. Short-term variations are represented by calcium-carbonate fluctuations in which the amount of $\mathrm{CaCO}_{3}$ is correlated to the grain size of the sediments; coarser sediments are associated with high carbonate content and abundant detrital material. Long-term variation corresponds to a gross grain-size change in the upper part of the sequence, where predominantly fine-grained sediments may indicate a gradual deepening of the lacustrine basin towards the Pliocene. Regional climatic changes and rift-related tectonism are possible causes of this variability in the sedimentation patterns.

The clay association is characterized by chlorite, illite, and smectite as dominant minerals, as well as mixed-layers clays, kaolinite, and palygorskite. Chlorite, mixed-layers clays, and illite increase at the expense of smectite below the pebble zone ( $335 \mathrm{mbsf})$. This is indicative of diagenetic processes related to the high geothermal gradient and to the chemistry of the evaporative pore waters, rather than to changes in the depositional environment.
\end{abstract}

\section{INTRODUCTION}

Site 652 (water depth $3470 \mathrm{~m}$; total sediment penetration 721 $\mathrm{m})$ is one of a transect of sites across the passive continental margin off eastern Sardinia. This transect was designed to document the timing and rate of extension and subsidence during the rifting of the Tyrrhenian basin (Fig. 1). Located on the lowermost of the tilted fault blocks that make up the inferred continent-ocean transition (Trincardi and Zitellini, 1987; Fabbri et al., 1981; Malinverno et al., 1981; Rehault et al., 1987a, b), this site lies on stretched and thinned continental crust (Steinmetz et al., 1983). Unlike Site 654, to the west of Site 652 and higher on the margin, Site 652 is characterized by a high geothermal gradient $\left(14^{\circ} \mathrm{C} / 100 \mathrm{~m}\right.$ today versus $4.2^{\circ} \mathrm{C} / 100 \mathrm{~m}$ at Site 654 ; Kastens, Mascle et al., 1987b), which according to models of continental rifting (McKenzie, 1978), may have been even higher in the past.

The sedimentary section recovered at Site 652 consists of 188 $\mathrm{m}$ of Pliocene-Pleistocene fossiliferous marine sediments, underlain by $533 \mathrm{~m}$ of barren gypsiferous and calcareous sandy and silty muds. The stratigraphic attribution of the Site 652 prePliocene sedimentary sequence to the late Miocene (Messinian) is questionable because of the lack of biostratigraphic and magnetostratigraphic constraints. In fact, the sediments contain no autochthonous fossils, and only a few fragments of possibly brackish-water ostracodes and reworked benthic foraminifers

\footnotetext{
${ }^{1}$ Kastens, K. A., Mascle, J., et al., 1990. Proc. ODP, Sci. Results, 107: College Station, TX (Ocean Drilling Program).

2 Lamont-Doherty Geological Observatory of Columbia University, Palisades, NY 10964.

${ }^{3}$ Department of Earth and Environmental Sciences, Queens College, Flushing, NY 11367.

4 Department of Earth Sciences, University of Milan, via Mangiagalli 34, 20133 Milano, Italy.

${ }_{5}^{5}$ Laboratory of Sedimentology and Geochemistry, University of Lille 1, SN5 59665 Villeneuve d'Asq, France.

${ }^{6}$ Schlumberger-Doll Research, Old Quarry Road, Ridgefield, CT 06877.
}

have been recovered (Kastens, Mascle et al., 1987b; Cita et al., this volume). Unfortunately, the age of the sediments cannot be determined uniquely on the basis of the magnetic record. Although the entire pre-Pliocene sequence seems to have been deposited during a reversed field (corresponding to the lower part of the Gilbert chron, 4.8-5.4 Ma), this interpretation implies an extraordinary high sedimentation rate (see Channel et al., this volume). Alternatively, if the erosional event represented by the 14-m-thick pebble interval between 324 and 338 mbsf can be regarded as a considerable time gap possibly corresponding to chron 5 (5.4-5.9 M.y.), the base of the hole could be correlated to the top of the Tortonian (M. Torii, pers. comm., 1987). Because of the absence of pollen-based dates, the attribution of the sequence to the Messinian is founded only on its stratigraphic position below the Pliocene (without a recognized discontinuity at the Pliocene/pre-Pliocene boundary) and on the presence of evaporites (e.g., gypsum and halite), particularly common below the pebble zone.

The depositional environment of the sediments recovered at Site 652 was interpreted as lacustrine (Kastens, Mascle et al., 1987 b), characterized by climatically controlled salinity fluctuations and frequent variations in the type and amount of terrigenous material (as influenced by climate and tectonics). Because of the low core recovery (less than $30 \%$ ) these fluctuations are difficult to recognize solely from core examination.

The objective of this study was to design a technique for processing and interpreting wireline logs (in-situ measurements) which would help delineate the evolution of the sedimentary record, during both deposition and burial diagenesis. Wireline logs are examined in combination with different core measurements and lithologic descriptions. The relationship between the log-derived geochemistry and mineralogy, and the physical properties of Hole 652A Messinian sediments is discussed, and the lithologic variations are interpreted with regard to the climatic and tectonic evolution of the central Tyrrhenian area.

Because of the continuous nature of log measurements, we believe that the technique employed here could offer a valid fu- 

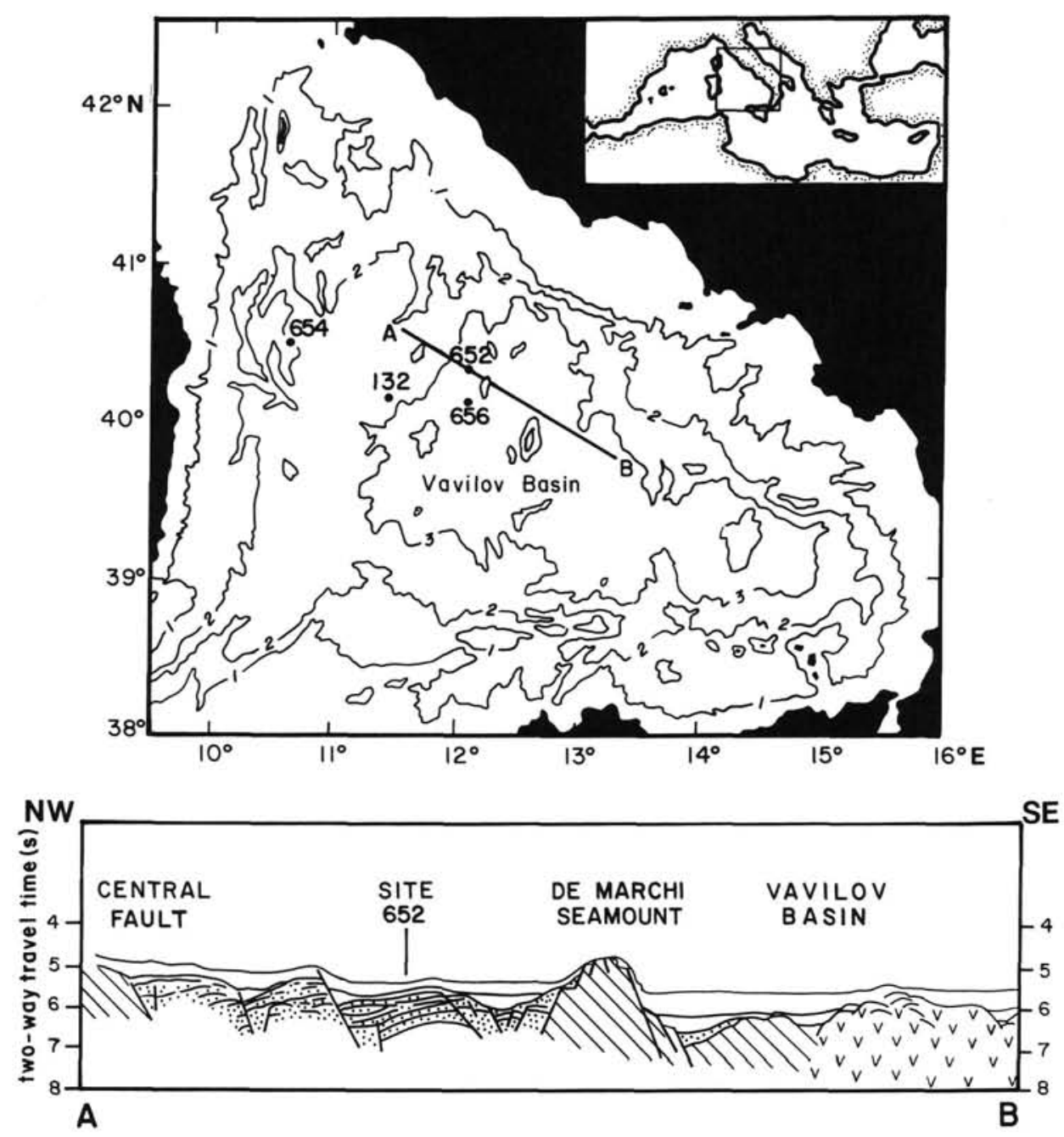

Figure 1. Simplified bathymetric map of the Tyrrhenian Sea and structural diagram of the lower Sardinian Margin and Vavilov Basin (isobaths in $\mathrm{km}$ ). Key to symbols: white = Quaternary-Pliocene sediments; dots = inferred pre-Pliocene sediments; hachure = acoustic basement (continental); vv = acoustic basement (basaltic). Modified after Rehault et al. (1987b).

ture alternative to traditional geochemical-mineralogical studies that rely entirely on limited core recovery.

\section{LOGGING DATA}

The logging data presented in this study consist of a suite of Schlumberger geophysical (sonic, resistivity, porosity, caliper) and geochemical (natural and induced gamma ray) logs recorded in Hole 652A from 170 to 364 mbsf (Figs. 2 and 3). A short description of the logging tools appears in the "Explanatory Notes" chapter (Kastens, Mascle et al., 1987a); the logging operations are detailed in the Site 652 chapter (Kastens, Mascle et al., 1987b).

Logging operations were carried out under adverse conditions that resulted from sudden and extreme variations in hole size. The presence of bridges (sediment obstructions) repeatedly caused the resistivity-sonic-caliper tool string to get stuck in the hole; as a result, the readings were affected by the frequent necessity to apply uneven pulls to free the tool. The quality of resistivity and sonic data, however, is generally acceptable. An exception is the $255-288$ mbsf interval (highlighted in Fig. 2) where the data are totally degraded. Because of an impassable bridge, no logging data could be recorded below 364 mbsf.
Washouts also impair the quality of logging data because the formation signal can be greatly attenuated by the borehole fluid. The three-arm caliper log recorded in Hole $652 \mathrm{~A}$ provided only a partial indication of the hole size (Kastens, Mascle et al., $1987 \mathrm{~b}$ ); in fact, the caliper readings range from as narrow as 6 in. to the maximum reading of 13.5 in., corresponding to its saturation level. Therefore, a tentative reconstruction of the borehole size has been performed, based on the traveltime measurements of the sonic tool (M. Greenberg, pers. comm., 1987). Eight radii measurements are generated at each depth (every $15.24 \mathrm{~cm}$ ) from the four transit times: an average value is then determined by eliminating data points until mean and median are separated by less than 2 standard deviations. The general trend of the reconstructed caliper log (Fig. 2) reflects the original $\log$ over the intervals where the tool string became stuck (260-275 mbsf and 310-332 mbsf), and provides a rough estimate of the hole size wherever the tool was saturated. Maximum hole size was estimated at around $20 \mathrm{in} .(51 \mathrm{~cm})$.

Such extreme variations in hole size-a perfectly smooth hole hole would be about $10 \mathrm{in} .(25 \mathrm{~cm})$ in diameter-are strictly related to the physical nature of the sediments drilled. According to shipboard core descriptions (Kastens, Mascle et al., 1987b), 

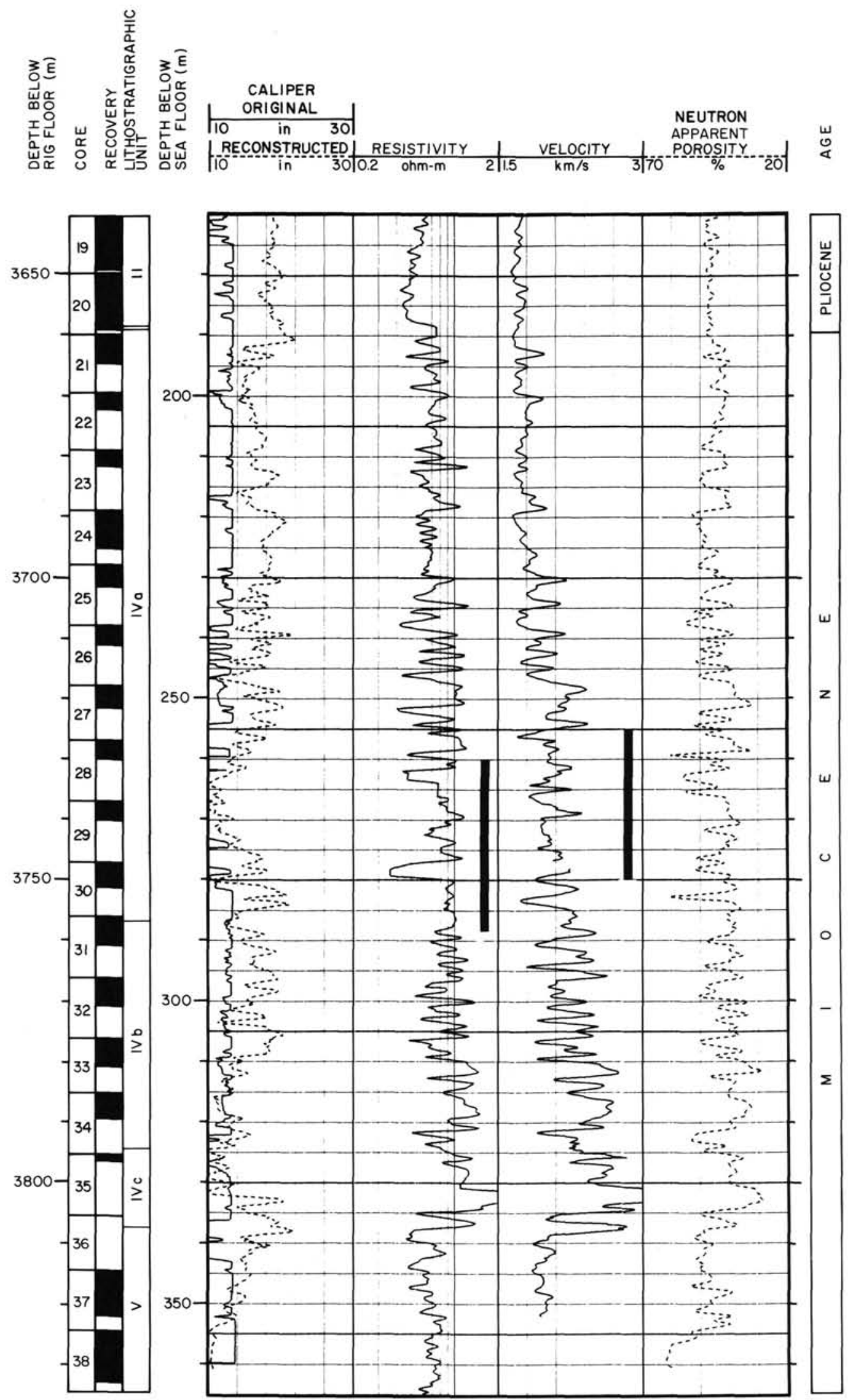

Figure 2. Logging data, core recovery, and lithostratigraphy as a function of depth in Hole 652A. A reconstruction of the hole size based on the sonic traveltimes is shown along with the original caliper log, saturated at its maximum reading (13.5 in.) throughout most of the hole. Apparent porosity from the neutron log is corrected for borehole conditions. Black bars indicate data considered unreliable because the sonic-resistivity-gamma ray string became stuck in the hole. Logging data were smoothed by using a 5 -point running average $(0.75-\mathrm{m}$-long interval). 

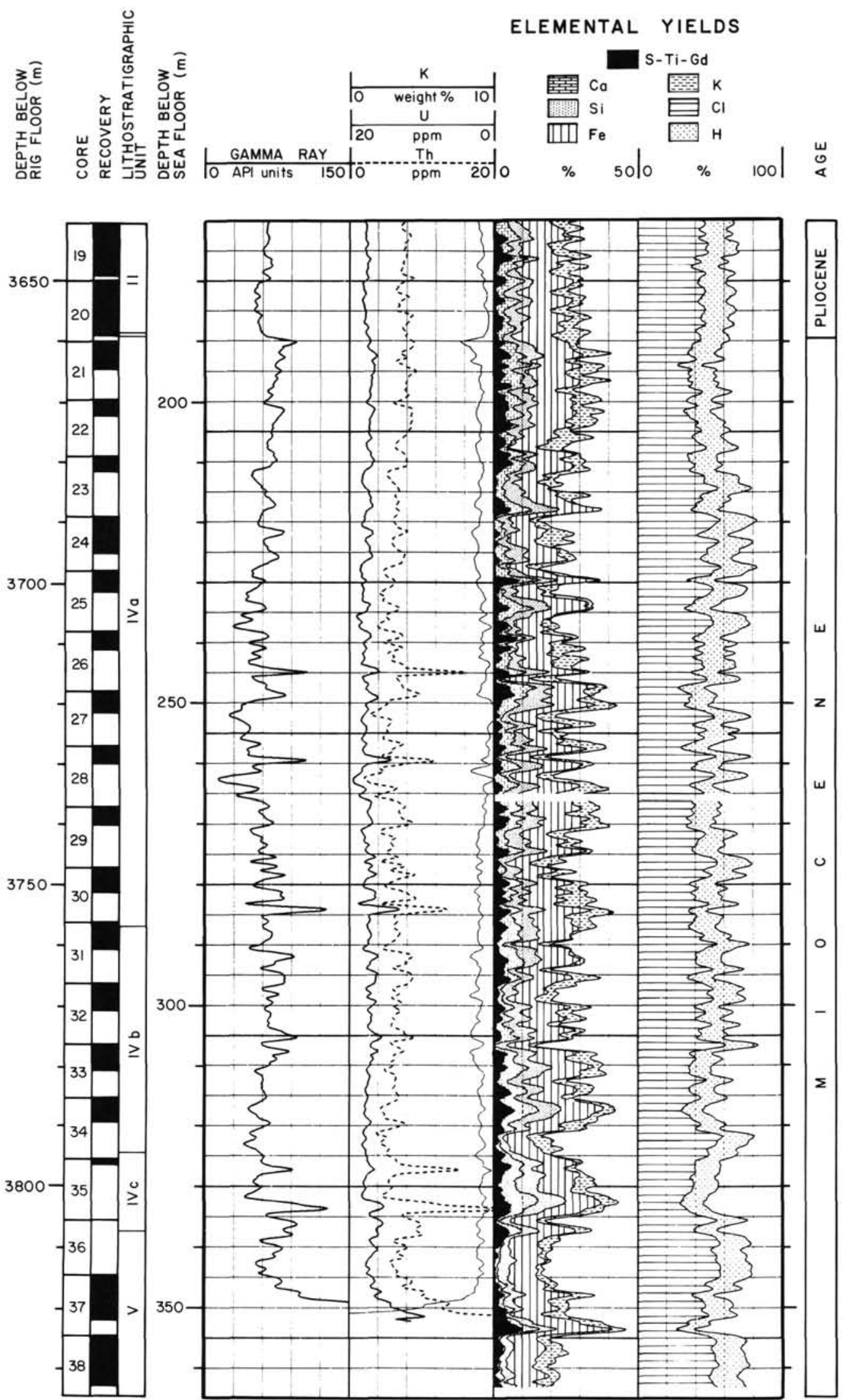

Figure 3. Logging data, core recovery, and lithostratigraphy as a function of depth in Hole 652A. Gamma ray and radioactive elements from natural spectral gamma ray log are corrected for borehole conditions. Relative elemental yields are from the induced gamma ray spectrometry log. Because of the frequent washouts the contribution of the solid fraction of the formation $(\mathrm{Ca}, \mathrm{Si}, \mathrm{K}$, and $\mathrm{Fe}$ ) is often less than $25 \%$. Logging data are smoothed by using a 5 -point running average $(0.75$-m-long interval). 
the sedimentary sequence consists of alternations of gypsumand carbonate-bearing silt and sand, slightly cemented in some intervals (relatively less porous on the neutron porosity $\log$ ), and unconsolidated calcareous clay and mud (highly porous on the neutron porosity $\log$ ). The caliper log directly reflects these lithologic variations, showing enlargement of the hole in association with clay and mud. Also, cross-correlation among logs recorded in Hole 652A during different runs confirms a consistency of reponse to hole-size/lithology variations.

Although all of the logging tools have been designed to minimize the effects mentioned above, corrections are required when logging conditions depart greatly from the standards under which the tool has been calibrated (Schlumberger, 1972). This is is particularly true for the neutron log (recorded without excentralizer because of pipe restrictions) and spectral gamma ray log. Corrections were applied to the neutron porosity (Fig. 2) and natural spectral gamma ray data (total signal and single radioactive elements, Fig. 3). These were made on the basis of the reconstructed caliper log which accounts for the hole size, type of drilling fluid (seawater), pressure, and temperature. For a comparison between the original and corrected neutron log and core measurements, see the Site 652 chapter (Kastens, Mascle et al., 1987b).

Even after borehole correction the neutron porosity is generally higher than $45 \%$. This is because of the presence of bound water in the clay minerals, which causes the neutron log to read too high. In this study we have not estimated any correction for the clay content, so we will consider the neutron log results as an indicator of the apparent porosity.

The effect of borehole size on the induced spectral gamma ray $\log$ is discussed briefly in the following section. The shipboard logging data (Figs. 2 and 3) were used to integrate the lithologic information obtained from the cores (Kastens, Mascle et al., 1987b), and to constrain lithostratigraphic boundaries that were uncertain due to the poor core recovery $(29 \%$ in the logged Messinian section). Based on the logs, the sedimentary sequence from 170 to 364 mbsf can be subdivided into five units:

1. The interval 170-189 mbsf (corresponding to the base of Lithostratigraphic Unit II, 55.4-188.2 mbsf, as determined by shipboard core analysis) consists of marly nannofossil ooze and exhibits apparent porosity greater than $50 \%$ and velocities around $1.7 \mathrm{~km} / \mathrm{s}$.

2. The interval $189-190$ mbsf (Lithostratigraphic Unit III, 188.2 to $188.6 \mathrm{mbsf}$ ) consists of low-carbonate, iron-rich clay. The Pliocene/Messinian boundary (189 mbsf) marks a drastic change in the lithologic and physical properties of the sediments; a physical properties change is also reflected by the smaller hole size.

3. The interval 190-324 mbsf (Lithostratigraphic Units IVA and IVB, 188.6-334.7 mbsf) consists of alternations of gypsiferous calcareous sand and silt with calcareous clay. The gypsiferous sediments are characterized on the logs by lower apparent porosity $(<45 \%)$ and higher velocity (up to $2.7 \mathrm{~km} / \mathrm{s}$ ), and by a higher $\mathrm{CaCO}_{3}$ content in the cores (Kastens, Mascle et al., 1987b).

4. The interval 324-338 mbsf (Lithostratigraphic Unit IVC, 334.7-344.8 mbsf) consists of a polygenic conglomerate characterized by apparent porosity around $(30 \%)$ and high velocity (up to $3.5 \mathrm{~km} / \mathrm{s}$ ). The $10-\mathrm{m}$ discrepancy between cores and logs at the top of this unit can be explained by the poor recovery in Cores 107-652-35R and $-36 \mathrm{R}(<10 \%)$.

5. The interval 338-364 mbsf (the top of Lithostratigraphic Unit V, 344.8-683.5 mbsf) consists of a dominantly clayey sequence containing thinly interbedded gypsiferous calcareous sand and silt, and anhydrite layers. This interval is characterized on the logs by high apparent porosity and low velocity, and by low $\mathrm{CaCO}_{3}$ content in the cores.

\section{PROCESSING OF LOGGING DATA}

The geochemical logs used in this study are based on the measurement of gamma ray energy using a sodium iodide (NaI[Tl]) detector. The natural spectral gamma ray tool measures the total radioactivity of the formation which depends on the concentration of three main radioactive isotopes: ${ }^{40} \mathrm{~K},{ }^{238} \mathrm{U}$, and ${ }^{232} \mathrm{Th}$. The detected spectrum is divided into five energy windows from 0.5 to $3 \mathrm{MeV}$, from which the concentrations of Th, U, and $\mathrm{K}$ are calculated. Because clay minerals have characteristic concentrations of these radioactive elements, spectral gamma ray data are commonly used for clay identification.

The induced gamma ray spectrometry tool (GST) measures the relative yield of gamma rays that result from the interactions of fast neutrons (emitted by a source) with the elements present in the formation. The number of gamma rays generated by inelastic (or capture) interactions and their energies form a spectrum which is recorded at each depth level (15.24-cm spacing), along with a background spectrum (Hertzog, 1978; Westaway et al., 1980). Statistical variations are reduced by maintaining a low logging speed, which was approximately $200 \mathrm{~m} / \mathrm{hr}$ in Hole $652 \mathrm{~A}$.

Each spectrum is then compared by the surface instrumentation with a library of standard spectra of the elements most commonly found in nature; a given standard corresponds to what the tool would measure if surrounded by that element only. Using a least-square method, the computer finally determines the linear combination of standards that best fit the recorded spectrum, and computes the proportion of the total spectrum attributed to each element, termed "elemental yields."

The tool used in the Ocean Drilling Program is operated in capture mode: the detected gamma ray spectrum is accumulated after the neutrons emitted from the source have slowed down to the thermal energy level $(0.025 \mathrm{eV})$ and are captured by the nucleii in the formation. In this mode the elements measured are: $\mathrm{Si}, \mathrm{Ca}, \mathrm{Fe}, \mathrm{K}, \mathrm{S}, \mathrm{Cl}, \mathrm{H}, \mathrm{Ti}$, and $\mathrm{Gd}$. Because this geochemical measurement does not account for other elements present in the formation (e.g., C, O, Al, Mg, and $\mathrm{Na}$ ), the relative yields must be normalized to obtain absolute elemental concentrations. At Hole $652 \mathrm{~A}$ this was carried out in three steps:

1. An estimate of the elemental yields from the original raw counts $(\mathrm{Si}, \mathrm{Ca}, \mathrm{Fe}, \mathrm{K}, \mathrm{S}, \mathrm{Gd}, \mathrm{Ti}, \mathrm{H}$, and $\mathrm{Cl}$ ) was made.

2. Dry weight percentages of the major elements present in the solid fraction of the sediments ( $\mathrm{Si}, \mathrm{Ca}, \mathrm{Fe}, \mathrm{K}, \mathrm{S}, \mathrm{Gd}$, and $\mathrm{Ti}$ ) were calculated from the elemental yields.

3. Dry weight fractions of the major oxides, carbonates, and sulfates $\left(\mathrm{SiO}_{2}, \mathrm{CaCO}_{3}, \mathrm{FeO}^{*}\right.$ [total iron], $\mathrm{K}_{2} \mathrm{O}, \mathrm{CaSO}_{4}$, $\mathrm{TiO}_{2}$ ) present in the sediments were estimated from the oxide fractions.

None of the above steps include an estimate of $\mathrm{Al}$ concentration. An additional measurement, provided by the aluminum activation clay tool (not available aboard JOIDES Resolution during Leg 107), is required to detect the gamma radiation generated by the interaction of thermal neutrons with $\mathrm{Al}$ nucleii (Hertzog and Schweitzer, 1986). This measurement is necessary because the thermal capture cross section of $\mathrm{Al}$ is very small, and the neutron-capture gamma ray intensities are too weak to contribute significantly to the GST spectrum (Hertzog et al., 1987).

Similarily, $\mathrm{Mg}$ and $\mathrm{Na}$ cannot be measured by capture spectroscopy, but are usually derived from the measurement of the photoelectric-effect cross-section made with the lithodensity tool (in this case not recorded because of the poor hole condi- 
tions). The $\mathrm{Al}$ abundance in the sediments of Hole $652 \mathrm{~A}$ is mostly related to clay minerals (where it ranges by weight from $12 \%$ in chlorites to $21 \%$ in kaolinites), but it is present in feldspars and rock fragments as well.

Chamley et al. (this volume) measured the major oxides of the Messinian clays on 58 selected samples from Sites 652 and 654 (Table 1). Assuming that the clay-size fraction $(<2 \mu \mathrm{m})$ of samples from Hole $652 \mathrm{~A}$ (Table 2) consists mostly of clay minerals, it is possible to get a rough estimate of the $\mathrm{Al}_{2} \mathrm{O}_{3}$ percent range in the size fraction of the sediment for which we do not account in our computation. For a clay-size fraction ranging from $5 \%$ to $75 \%, \mathrm{Al}_{2} \mathrm{O}_{3}$ would vary from $1 \%$ to $16 \%$ for a clay formed of $100 \%$ chlorite, and from $2 \%$ to $29 \%$ for a clay formed of $100 \%$ kaolinite. A similar estimate for $\mathrm{MgO}$ and $\mathrm{Na}_{2} \mathrm{O}$ yields the following values: $\mathrm{MgO}=0.6 \%-9 \%$ (chlorite), $\mathrm{MgO}=0.08 \%-1.24 \%$ (kaolinite) and $\mathrm{Na}_{2} \mathrm{O}=0.04 \%-0.6 \%$ (chlorite), $\mathrm{Na}_{2} \mathrm{O}=0.03 \%-0.5 \%$ (kaolinite). Therefore, all the following estimates from the geochemical logs are to be regarded as semiquantitative because they represent overestimates of the actual oxide weight fractions.

The yields of the nine elements which contribute to the total gamma ray spectrum, recomputed from the raw count rates, are shown in Figure 3. The proportions of $\mathrm{H}$ and $\mathrm{Cl}$ (Fig. 3, righthand side), elements that are particularly abundant in the borehole fluid and in the pore volume of the formation, range from $50 \%$ to $80 \%$ of the total signal. This is a reflection of the common hole-size variations (see the reconstructed caliper curve, Fig. 2) caused by changes in the physical properties of the sediments (concentration increases with increasing porosity).

These relative elemental concentrations are related to the absolute concentrations by a depth-dependent normalization factor (Hertzog et al., 1987):

$$
\mathrm{Wt}_{\mathrm{i}}=\mathrm{FY}_{\mathrm{i}} / \mathrm{S}_{\mathrm{i}}
$$

where

$$
\begin{aligned}
\mathrm{Wt}_{\mathrm{i}} & =\text { absolute elemental concentration, } \\
\mathrm{F} & =\text { normalization factor, } \\
\mathrm{Y}_{\mathrm{i}} & =\text { relative elemental yield, } \\
\mathrm{S}_{\mathrm{i}} & =\text { tool spectral sensitivity. }
\end{aligned}
$$

The sensitivity $\left(\mathrm{S}_{\mathrm{i}}\right)$ is a tool constant, measured in the laboratory, which depends on the capture cross-section of each element measured by the GST tool: for example, $\mathrm{S}_{\mathrm{i}}$ is higher for Gd (large capture cross section) than for $\mathrm{Si}$ (small capture cross section). $\mathrm{F}$ is calculated at each logging depth, using a method that accounts for the presence of $\mathrm{C}$ and $\mathrm{O}$ and associates each element to a single oxide or carbonate. Because the sum of the oxides in a rock is $100 \%, \mathrm{~F}$ is given by:

$$
\mathrm{F}\left(\Sigma_{\mathrm{i}} \mathrm{X}_{\mathrm{i}} \mathrm{Y}_{\mathrm{i}} / \mathrm{S}_{\mathrm{i}}\right)+\mathrm{X}_{\mathrm{K}} \mathrm{Wt}_{\mathrm{K}}+\mathrm{X}_{\mathrm{Al}} \mathrm{Wt}_{\mathrm{Al}}=100
$$

where

$$
\begin{aligned}
\mathrm{X}_{\mathrm{i}}= & \text { dry weight of oxide or carbonate/ } \\
& \text { dry weight of element } \mathrm{i} \text {, } \\
\mathrm{X}_{\mathrm{K}}= & \text { dry weight of } \mathrm{K}_{2} \mathrm{O} / \text { dry weight of } \\
& \mathrm{K}, \\
\mathrm{Wt}_{\mathrm{K}}= & \text { dry weight } \mathrm{K} \text { from natural spectral } \\
& \text { gamma ray, } \\
\mathrm{X}_{\mathrm{Al}} \mathrm{Wt}_{\mathrm{Al}}= & 0 \text { (not measured at Hole } 652 \mathrm{~A}) .
\end{aligned}
$$

Equation (2) is then used to compute the absolute weight fraction for each element. Among the estimated elemental fractions is gadolinium, a rare earth whose contribution to the gamma-ray detected spectrum can be quite high, due to its large capture cross-section.

As the final step, oxides or carbonates associated with each element have have been computed from the elemental weight fraction by using the appropriate conversion factor (ratio of the oxide or carbonate molecular weight to that of the measured element):

\begin{tabular}{clc}
\hline Element & Oxide/carbonate & Conversion factor \\
\hline $\mathrm{Si}$ & $\mathrm{SiO}_{2}$ & 2.139 \\
$\mathrm{Ca}$ & $\mathrm{CaCO}_{3}$ & 2.497 \\
$\mathrm{Fe}$ & $\mathrm{FeO}^{*}$ (total iron) & 1.358 \\
$\mathrm{~K}$ & $\mathrm{~K}_{2} \mathrm{O}$ & 1.205 \\
$\mathrm{~S}$ & $\mathrm{CaSO}_{4}$ & 4.25 \\
$\mathrm{Ti}$ & $\mathrm{TiO}_{2}$ & 1.668 \\
\hline
\end{tabular}

The results are shown in Figure 4. At least three calciumbearing minerals are present in the upper Messinian sediments of Hole $652 \mathrm{~A}$ (calcite, gypsum-anhydrite, and, to a lesser degree, dolomite), so it was first necessary to estimate the amount of the original $\mathrm{Ca}$ weight fraction required to form each of these three minerals. We have assumed that the amount of dolomite in the studied interval is very small (calcite is the dominant carbonate phase down to 410 mbsf; see Pierre and Rouchy, this volume), and that no pyrite is present in the sediments. Thus we derived the calcium content of the gypsum from the sulfur curve, and that of calcite by subtraction from total calcium.

A test of the quality of the model is given by the closure sum, which should be $100 \%$ when the model assumptions reflect the true composition of the formation. At Hole $652 \mathrm{~A}$ the closure sum ranges between $93.5 \%$ and $100 \%$. We reemphasize, however, that this result does not account for the $\mathrm{Al}_{2} \mathrm{O}_{3}, \mathrm{MgO}$, and $\mathrm{Na}_{2} \mathrm{O}$ fractions (see "Processing of Logging Data" section above), and therefore it is to be regarded as qualitative only.

Table 1. Average chemical composition of Messinian clays at Sites 652 and 654 from microprobe analyses (calculated after Chamley et al., this volume).

\begin{tabular}{lccccccccc}
\hline & $\begin{array}{c}\mathrm{SiO}_{2} \\
(\%)\end{array}$ & $\begin{array}{c}\mathrm{Al}_{2} \mathrm{O}_{3} \\
(\%)\end{array}$ & $\begin{array}{c}\mathrm{MgO} \\
(\%)\end{array}$ & $\begin{array}{c}\mathrm{CaO} \\
(\%)\end{array}$ & $\begin{array}{c}\mathrm{Fe}_{2} \mathrm{O}_{3} \\
(\%)\end{array}$ & $\begin{array}{l}\mathrm{TiO}_{2} \\
(\%)\end{array}$ & $\begin{array}{c}\mathrm{Na}_{2} \mathrm{O} \\
(\%)\end{array}$ & $\begin{array}{c}\mathrm{K}_{2} \mathrm{O} \\
(\%)\end{array}$ & $\begin{array}{c}\text { Number of } \\
\text { samples }\end{array}$ \\
\hline Site 652 & & & & & & & & & \\
Illite & 50.20 & 30.00 & 3.50 & 0.66 & 6.30 & 0.50 & 1.12 & 7.45 & 14 \\
Smectite & 52.76 & 23.57 & 4.70 & 1.50 & 9.88 & 0.39 & 1.75 & 4.97 & 4 \\
Chlorite & 35.91 & 21.76 & 11.45 & 0.76 & 25.60 & 0.74 & 0.82 & 2.58 & 12 \\
Kaolinite & 51.99 & 38.72 & 1.66 & 0.43 & 3.34 & 0.70 & 0.61 & 2.63 & 10 \\
Site 654 & & & & & & & & & \\
Illite & 50.04 & 31.00 & 2.98 & 0.44 & 5.83 & 0.51 & 1.28 & 7.88 & 6 \\
Smectite & 52.48 & 22.86 & 4.83 & 1.08 & 11.65 & 0.68 & 1.20 & 4.22 & 3 \\
Chlorite & 34.19 & 23.40 & 10.63 & 0.52 & 27.36 & 0.41 & 0.98 & 2.43 & 5 \\
Kaolinite & 49.94 & 36.72 & 1.65 & 0.45 & 3.90 & 0.29 & 3.03 & 3.91 & 4 \\
\hline
\end{tabular}


Table 2. $\mathrm{CaCO}_{3}$ and grain size analyses of selected samples at Hole 652A (this study).

\begin{tabular}{|c|c|c|c|c|c|}
\hline $\begin{array}{l}\text { Core, section, } \\
\text { interval }(\mathrm{cm})\end{array}$ & $\begin{array}{l}\text { Depth } \\
\text { (mbsf) }\end{array}$ & $\begin{array}{c}\mathrm{CaCO}_{3} \\
(\%)\end{array}$ & $\begin{array}{l}\text { Sand } \\
(\%)\end{array}$ & $\begin{array}{l}\text { Silt } \\
(\%)\end{array}$ & $\begin{array}{l}\text { Clay } \\
(\%)\end{array}$ \\
\hline \multicolumn{6}{|l|}{$107-652 \mathrm{~A}-$} \\
\hline $21 \mathrm{R}-1,48-50$ & 190.29 & 19.6 & 0.2 & 50.9 & 48.9 \\
\hline $21 \mathrm{R}-2,50-52$ & 191.81 & 22.9 & 0.2 & 63.9 & 35.9 \\
\hline $21 \mathrm{R}-3,49-51$ & 193.30 & 21.6 & 0.0 & 79.0 & 21.0 \\
\hline $22 \mathrm{R}-1,50-52$ & 200.21 & 18.9 & 0.0 & 32.0 & 68.0 \\
\hline $22 \mathrm{R}-2,54-56$ & 201.75 & 22.0 & 0.0 & 61.0 & 39.0 \\
\hline $23 \mathrm{R}-1,49-51$ & 209.60 & 25.0 & 1.8 & 84.0 & 14.2 \\
\hline $23 R-2,49-51$ & 211.10 & 19.3 & 0.0 & 25.0 & 75.0 \\
\hline $24 \mathrm{R}-1,7-9$ & 218.78 & 12.0 & 2.0 & 61.0 & 37.0 \\
\hline $24 \mathrm{R}-1,54-56$ & 219.25 & 25.9 & 10.2 & 56.6 & 32.2 \\
\hline $24 \mathrm{R}-1,141-143$ & 220.12 & 17.0 & - & 47.0 & 53.0 \\
\hline $24 \mathrm{R}-2,2-5$ & 220.23 & 19.0 & - & 52.0 & 48.0 \\
\hline $24 \mathrm{R}-2,50-52$ & 220.71 & 20.3 & 0.2 & 31.9 & 67.9 \\
\hline $24 \mathrm{R}-2,71-74$ & 220.93 & 18.0 & - & 42.8 & 57.2 \\
\hline $24 \mathrm{R}-3,8-11$ & 221.80 & 17.0 & - & 40.2 & 59.8 \\
\hline $24 \mathrm{R}-3,50-52$ & 222.35 & - & 0.0 & 61.0 & 39.0 \\
\hline $24 \mathrm{R}-3,59-61$ & 222.30 & 14.0 & - & 46.1 & 53.9 \\
\hline $24 R-4,50-52$ & 223.71 & - & 0.2 & 75.2 & 24.6 \\
\hline $24 R-4,72-74$ & 223.93 & 20.0 & - & 46.0 & 54.0 \\
\hline $24 \mathrm{R}-4,104-106$ & 224.25 & 28.0 & 12.6 & 69.9 & 17.5 \\
\hline $25 \mathrm{R}-1,80-82$ & 229.13 & - & 0.0 & 55.0 & 45.0 \\
\hline $25 \mathrm{R}-2,80-82$ & 230.71 & - & 2.6 & 82.3 & 15.1 \\
\hline $26 \mathrm{R}-1,50-52$ & 238.61 & 27.1 & 0.2 & 66.9 & 32.9 \\
\hline $26 \mathrm{R}-2,53-55$ & 240.01 & - & 0.0 & 51.0 & 49.0 \\
\hline $27 \mathrm{R}-1,50-52$ & 248.21 & 25.7 & 0.6 & 50.7 & 48.7 \\
\hline $27 \mathrm{R}-2,50-52$ & 249.71 & 28.9 & 1.6 & 82.0 & 16.4 \\
\hline $28 \mathrm{R}-1,50-52$ & 257.91 & 22.5 & 0.4 & 74.2 & 25.4 \\
\hline $28 \mathrm{R}-2,50-52$ & 259.41 & 21.4 & 0.0 & 53.0 & 48.0 \\
\hline $30 \mathrm{R}-1,51-52$ & 277.22 & 25.5 & 0.4 & 74.7 & 24.9 \\
\hline $30 \mathrm{R}-2,51-53$ & 278.72 & 24.8 & 3.6 & 83.5 & 12.9 \\
\hline $30 \mathrm{R}-3,49-51$ & 280.20 & - & 2.2 & 85.6 & 12.2 \\
\hline $31 \mathrm{R}-1,47-49$ & 286.78 & 25.5 & 0.2 & 67.9 & 31.9 \\
\hline $31 \mathrm{R}-2,38-40$ & 288.19 & 27.2 & 2.8 & 75.8 & 21.4 \\
\hline $31 R-3,49-51$ & 289.80 & 32.0 & 5.0 & 81.2 & 13.8 \\
\hline $32 \mathrm{R}-1,27-29$ & 296.18 & 19.8 & 0.0 & 70.9 & 20.1 \\
\hline $32 \mathrm{R}-2,43-45$ & 297.81 & - & 7.8 & 82.9 & 9.3 \\
\hline $32 \mathrm{R}-3,43-45$ & 299.34 & 21.0 & 0.2 & 60.9 & 32.9 \\
\hline $33 \mathrm{R}-1,21-23$ & 305.82 & 25.0 & - & 59.8 & 40.2 \\
\hline $33 \mathrm{R}-1,75-77$ & 306.36 & 33.1 & - & - & - \\
\hline $33 \mathrm{R}-1,110-112$ & 306.71 & 25.0 & - & 83.0 & 17.0 \\
\hline $33 R-2,54-56$ & 307.65 & 18.0 & - & 64.0 & 36.0 \\
\hline $33 R-2,111-113$ & 308.22 & 32.9 & - & - & - \\
\hline $33 R-2,145-147$ & 308.56 & 28.0 & 19.1 & 65.5 & 15.4 \\
\hline $33 \mathrm{R}-3,29-31$ & 308.9 & 34.9 & - & - & - \\
\hline $33 \mathrm{R}-3,33-35$ & 308.94 & 30.0 & 27.6 & 61.5 & 10.9 \\
\hline $33 R-3,105-107$ & 309.66 & 23.0 & 7.4 & 86.7 & 5.9 \\
\hline $34 \mathrm{R}-1,36-38$ & 315.67 & 23.0 & 2.2 & 86.1 & 11.7 \\
\hline $34 \mathrm{R}-1,40-42$ & 315.71 & 31.7 & - & - & - \\
\hline $34 \mathrm{R}-1,131-133$ & 316.62 & 25.0 & 1.2 & 82.5 & 16.3 \\
\hline $34 \mathrm{R}-2,40-42$ & 317.21 & 2 & - & - & - \\
\hline $34 \mathrm{R}-2,59-61$ & 317.40 & 30.0 & 46.7 & 48.3 & 5.0 \\
\hline $34 \mathrm{R}-2,110-112$ & 317.91 & 25.0 & - & 85.0 & 15.0 \\
\hline $34 \mathrm{R}-3,22-25$ & 318.54 & 23.0 & 3.9 & 89.1 & 7.0 \\
\hline $34 \mathrm{R}-3,40-42$ & 318.71 & 23.2 & - & - & - \\
\hline $34 \mathrm{R}-3,75-77$ & 319.06 & 29.0 & 33.4 & 60.7 & 5.9 \\
\hline $35 \mathrm{R}-1,34-36$ & 325.35 & 26.4 & - & - & - \\
\hline $37 \mathrm{R}-1,60-63$ & 344.92 & 5.0 & 1.1 & 65.1 & 33.8 \\
\hline $37 \mathrm{R}-1,130-132$ & 345.61 & 11.0 & - & 58.0 & 42.0 \\
\hline $37 \mathrm{R}-2,30-33$ & 346.11 & 12.0 & - & 58.0 & 42.0 \\
\hline $37 R-2,105-107$ & 346.86 & 8.0 & - & - & - \\
\hline $37 \mathrm{R}-3,24-27$ & 347.55 & 6.0 & - & 66.5 & 33.5 \\
\hline $37 R-3,105-108$ & 348.37 & 12.0 & - & 58.8 & 41.5 \\
\hline $37 R-4,44-47$ & 349.25 & 26.0 & 50.3 & 42.3 & 7.4 \\
\hline $37 R-4,104-108$ & 349.86 & 17.0 & 0.6 & 53.7 & 45.7 \\
\hline $37 R-5,62-65$ & 350.93 & 7.0 & 0.3 & 89.4 & 20.3 \\
\hline $37 R-5,103-106$ & 351.32 & 11.0 & 11.0 & 61.4 & 27.6 \\
\hline $38 \mathrm{R}-1,12-15$ & 354.13 & 12.0 & - & 68.0 & 32.0 \\
\hline $38 \mathrm{R}-1,109-112$ & 355.10 & 9.0 & - & 54.0 & 36.0 \\
\hline $38 \mathrm{R}-2,7-12$ & 355.60 & 18.0 & - & 70.0 & 30.0 \\
\hline $38 \mathrm{R}-2,79-82$ & 356.30 & 14.0 & - & 62.3 & 37.7 \\
\hline $38 \mathrm{R}-3,29-32$ & 357.30 & 17.0 & - & 64.0 & 36.0 \\
\hline $38 \mathrm{R}-3,83-85$ & 357.84 & 14.0 & 46.0 & 32.7 & 21.3 \\
\hline $38 \mathrm{R}-4,55-59$ & 359.07 & 19.0 & 1.9 & 54.9 & 43.2 \\
\hline $38 \mathrm{R}-4,84-88$ & 359.36 & 18.0 & 5.0 & 50.6 & 44.4 \\
\hline $38 \mathrm{R}-5,5-9$ & 360.07 & 12.0 & - & 62.5 & 37.5 \\
\hline $38 \mathrm{R}-5,130-133$ & 361.31 & 19.0 & - & 64.0 & 40.0 \\
\hline
\end{tabular}

\section{RESULTS}

The most striking feature observed in Figure 4 is given by the inverse correlation of $\mathrm{CaCO}_{3}$ and $\mathrm{SiO}_{2} \cdot \mathrm{CaCO}_{3}$ fluctuates considerably, with values from 0 to $50 \% . \mathrm{CaCO}_{3}$-rich intervals are generally characterized by low apparent porosity and high velocity (Figs. 2 and 8), and are interpreted to be more cemented layers that may correspond to the sand and silt beds observed in the cores (see below). Conversely, intervals high in $\mathrm{SiO}_{2}$ (and that exhibit apparent high porosity-low velocity values) have been interpreted as fine-grained, clay-rich levels. This seems to be supported by the observation that they are coupled locally with high $\mathrm{FeO}^{*}$ values (iron is present in various amounts in clay minerals such as chlorite, smectite, and illite, all present at Hole $652 \mathrm{~A}$ as seen from Tables 1 and 3 ). Iron-rich smectites (beidellites-nontronites) are quite common in Messinian sediments of the Tyrrhenian. The Messinian clays of Deep Sea Drilling Project (DSDP) Site 132 (central Tyrrhenian basin) contain large amounts of well-crystallized smectites (Chamley et al., 1978), which locally represent up to $100 \%$ of the clay minerals. The predominance of smectite characterizes not only the marine record but also the Messinian sediments from the circum-Tyrrhenian area (Chamley et al., 1978; Chamley and Robert, 1980). At Hole $652 \mathrm{~A}$, however, the clay association in the studied interval is characterized by dominant chlorite and, subordinately, illite and smectite (Table 3 and Chamley et al., this volume). According to microprobe analyses by Chamley et al. (this volume; Table 1) chlorites have by far the highest $\mathrm{Fe}_{2} \mathrm{O}_{3}$ values $(25.6 \%)$; thus we relate the fluctuations of the log-computed iron curve primarily to the abundance of this mineral, and secondarily, to the abundance of smectite. This interpretation would also explain the lower radioactivity values observed in most of the clayrich levels, although we cannot rule out the possibility that washouts are responsible for the signal attenuation.

The $\mathrm{FeO}^{*}$ curve also accounts for the presence of iron oxides (goethite) in the clay-size fraction (Table 3, Fig. 4, and Chamley et al., this volume), and of ankerite (Fe-rich dolomite, Pierre and Rouchy, this volume); it shows a marked increase in the 334-364 mbsf interval, immediately below the pebble zone, where reddish-brown oxidized zones are observed (Kastens, Mascle et al., 1987b).

The relationship between fluctuations in calcium carbonate content and grain size was tested on 40 core samples from three intervals selected on the basis of the estimated $\mathrm{CaCO}_{3}$ and $\mathrm{SiO}_{2}$ fractions (Fig. 4): (1) Interval 1, 218.70-228.4 mbsf (Core 107652A-24R); (2) Interval 2, 305.60-325.0 mbsf (Cores 107-652A$33 \mathrm{R}$ and $-34 \mathrm{R}$ ); and (3) Interval 3, 344.30-363.7 mbsf (Cores 107-652A-37R and -38R).

Intervals 2 and 3 are characterized on the logs by high and low carbonate values respectively, whereas within Interval 1 the carbonate curve is quite variable. Carbonate content, grain-size analyses, as well as bulk rock and clay analyses by X-ray diffraction were performed on each sample (Tables 2 and 3). A description of the techniques used in these analyses is given in Cita et al. (this volume) and Chamley et al. (this volume). The results, along with log-estimated oxide and carbonate contents are presented in Figure 5. Because core recovery is low and the sampling rate is only two samples per section, a comparison is made between the general trends observed in cores and logs, rather than between single points.

The three intervals consist of clayey silt and interlayered sand and silty sand. The 305.6-325.0 mbsf interval (Cores 107-652A$33 \mathrm{R}$ and $-34 \mathrm{R}$ ) has the highest $\mathrm{CaCO}_{3}$ values both for cores and logs, and has the lowest clay-size fraction (average $=16 \%$ ). It also exhibits the highest calcite/clay mineral ratio. Conversely, the 344.3-363.7 mbsf interval (Cores 107-652A-37R and -38R) has the lowest carbonate values, the highest clay-size fraction (average $=36 \%$ ), and the lowest calcite/clay mineral ratio. The 


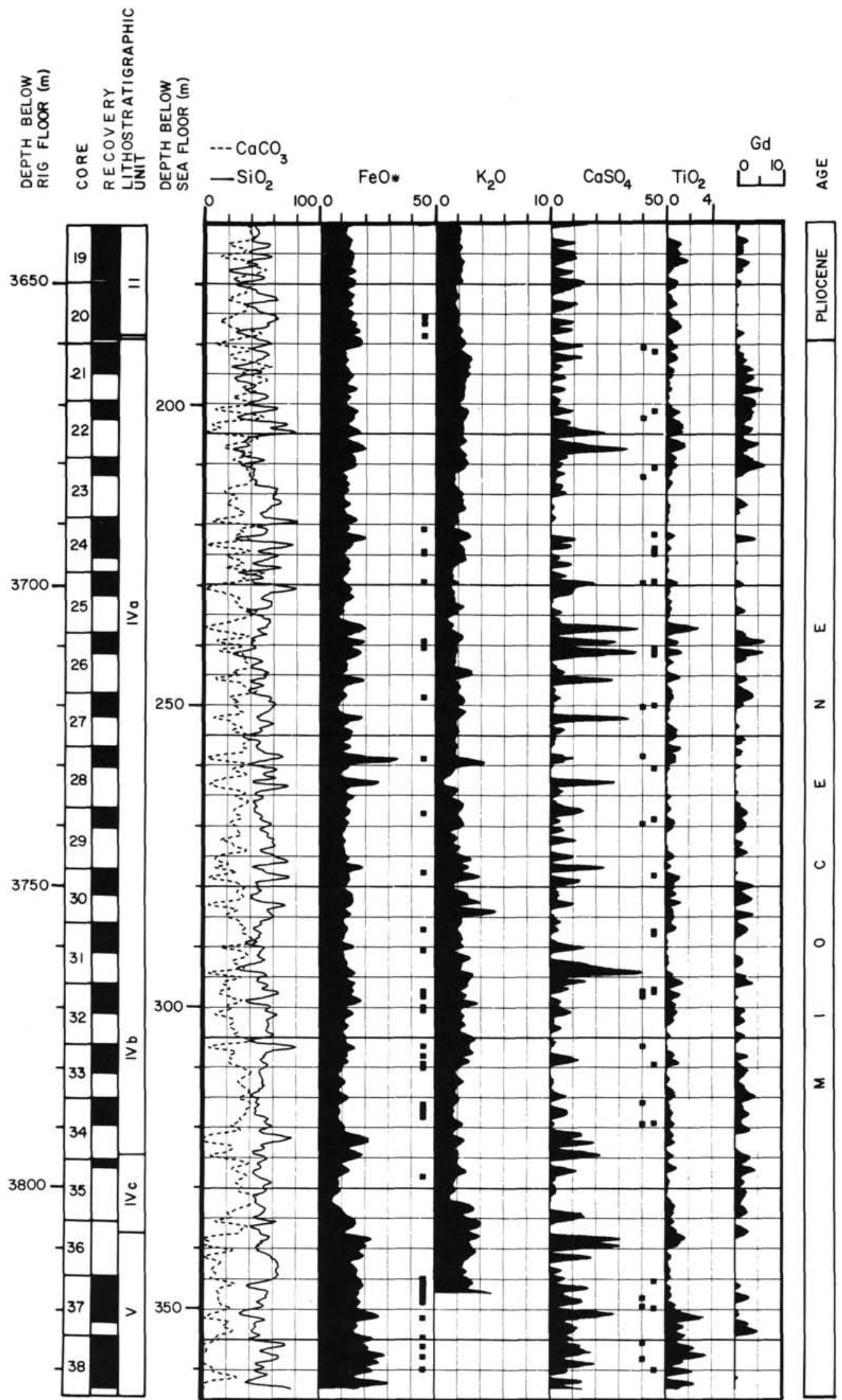

Figure 4. Log-computed oxides and carbonates (both dry-weight \%). Gadolinium (Gd) in ppm. Black squares show the occurrence of iron oxides (goethite) from clay analyses (this study, and Chamley et al., this volume), and of gypsum and anhydrite from smear slides (dominant and minor lithology to the right and left respectively, from Kastens, Mascle et al., 1987b). The black bars indicate the three intervals selected for the qualitative calibration, based on $\mathrm{Ca}$ and $\mathrm{Si}$ variations. 
Table 3. Clay mineralogy of selected samples at Hole $652 \mathrm{~A}$ (this study).

\begin{tabular}{|c|c|c|c|c|c|c|c|c|}
\hline $\begin{array}{l}\text { Core, section, } \\
\text { interval }(\mathrm{cm})\end{array}$ & $\begin{array}{c}\text { Chlorite } \\
(\%)\end{array}$ & $\begin{array}{l}\text { Smectite } \\
(\%)\end{array}$ & $\begin{array}{c}\text { Kaolinite } \\
(\%)\end{array}$ & $\begin{array}{l}\text { Illite } \\
(\%)\end{array}$ & $\begin{array}{c}\text { Mixed } \\
\text { layer } \\
\text { clays } \\
(\%)\end{array}$ & Quartz & Feldspar & Goethite \\
\hline \multicolumn{9}{|l|}{$107-652 \mathrm{~A}-$} \\
\hline $24 \mathrm{R}-1,7-9$ & 30 & 25 & 15 & 25 & 5 & ++ & + & \\
\hline $24 \mathrm{R}-1,141-143$ & 35 & 20 & 15 & 25 & 5 & ++ & + & \\
\hline $24 R-2,2-5$ & 35 & 20 & 15 & 25 & 5 & ++ & + & + \\
\hline $24 \mathrm{R}-2,71-74$ & 35 & 25 & 15 & 25 & - & ++ & & \\
\hline $24 \mathrm{R}-3,8-11$ & 35 & 15 & 15 & 30 & 5 & ++ & + & \\
\hline $24 \mathrm{R}-3,59-61$ & 30 & 25 & 15 & 30 & - & ++ & + & \\
\hline $24 \mathrm{R}-4,72-74$ & 30 & 25 & 20 & 25 & - & ++ & + & + \\
\hline $24 \mathrm{R}-4,104-106$ & 25 & 35 & 15 & 25 & - & + & + & + \\
\hline $33 \mathrm{R}-1,21-23$ & 30 & 10 & 25 & 25 & 10 & +++ & + & \\
\hline $33 R-1,110-112$ & 30 & 15 & 20 & 25 & 10 & ++ & + & \\
\hline $33 R-2,54-56$ & 25 & 30 & 15 & 25 & 5 & +++ & + & + \\
\hline $33 R-2,145-147$ & 25 & 35 & 20 & 20 & - & + & + & \\
\hline $33 R-3,33-35$ & 20 & 40 & 15 & 20 & 5 & ++ & + & \\
\hline $33 R-3,105-107$ & 30 & 20 & 20 & 25 & 5 & ++ & + & + \\
\hline $34 \mathrm{R}-1,21-23$ & 15 & 55 & 10 & 15 & 5 & + & + & + \\
\hline $34 \mathrm{R}-1,36-38$ & 30 & 20 & 20 & 25 & 5 & ++ & + & + \\
\hline $34 \mathrm{R}-2,59-61$ & 35 & 10 & 20 & 25 & 10 & ++ & + & + \\
\hline $34 \mathrm{R}-2,110-112$ & 30 & 5 & 20 & 35 & 10 & ++ & ++ & \\
\hline $34 \mathrm{R}-3,22-25$ & 35 & 10 & 20 & 30 & 5 & ++ & + & \\
\hline $34 \mathrm{R}-3,75-77$ & 45 & 5 & 15 & 25 & 10 & ++ & + & \\
\hline $37 \mathrm{R}-1,60-63$ & 30 & 5 & 20 & 35 & 10 & ++ & + & ++ \\
\hline $37 \mathrm{R}-1,130-132$ & 35 & - & 20 & 30 & 15 & ++ & + & + \\
\hline $37 \mathrm{R}-2,30-33$ & 35 & 5 & 15 & 30 & 15 & ++ & + & \\
\hline $37 \mathrm{R}-2,105-107$ & 30 & 20 & 15 & 30 & 5 & ++ & + & \\
\hline $37 \mathrm{R}-3,24-27$ & 25 & 10 & 15 & 35 & 15 & ++ & + & + \\
\hline $37 R-3,105-108$ & 35 & 5 & 15 & 30 & 15 & ++ & + & \\
\hline $37 R-4,44-47$ & 35 & 15 & 15 & 25 & 10 & ++ & + & \\
\hline $37 R-4,104-108$ & 30 & 10 & 20 & 30 & 10 & ++ & & \\
\hline $37 R-5,62-65$ & 35 & 15 & 15 & 25 & 10 & ++ & + & + \\
\hline $37 R-5,103-106$ & 35 & 15 & 15 & 25 & 10 & ++ & & \\
\hline $38 \mathrm{R}-1,12-15$ & 35 & - & 20 & 30 & 15 & ++ & + & + \\
\hline $38 \mathrm{R}-1,109-112$ & 35 & 15 & 15 & 30 & 5 & ++ & + & \\
\hline $38 R-2,7-12$ & 30 & 10 & 15 & 30 & 15 & ++ & + & + \\
\hline $38 \mathrm{R}-2,79-82$ & 30 & 15 & 15 & 30 & 10 & ++ & & \\
\hline $38 \mathrm{R}-3,29-32$ & 30 & 15 & 15 & 25 & 15 & ++ & + & + \\
\hline $38 \mathrm{R}-3,83-85$ & 35 & 10 & 15 & 30 & 10 & ++ & & \\
\hline $38 \mathrm{R}-4,55-59$ & 35 & 10 & 15 & 30 & 10 & ++ & + & \\
\hline $38 \mathrm{R}-4,84-88$ & 35 & 10 & 15 & 35 & 5 & ++ & & \\
\hline $38 \mathrm{R}-5,5-9$ & 40 & 5 & 15 & 30 & 10 & +++ & + & \\
\hline $38 \mathrm{R}-5,130-133$ & 35 & 10 & 15 & 30 & 10 & ++ & ++ & \\
\hline
\end{tabular}

Note: $+=$ rare $++=$ common $+++=$ abundant .

uppermost interval (Core 107-652A-24R) displays intermediate $\mathrm{CaCO}_{3}$ values in a dominantly clayey lithology (greatest clay-size fraction), as well as an intermediate calcite/clay mineral ratio and the lowest quartz/clay mineral ratio.

The increase in $\mathrm{FeO}^{*}$ observed on the logs in the lowermost interval results from an increase in chlorite and iron oxides. The observed increase in $\mathrm{CaSO}_{4}$ results from the presence of frequent fine gypsum layers. In general, however, gypsum occurrence is not correlated with carbonate abundance.

Intervals 2 and 3 both display similar $\mathrm{SiO}_{2}$ values, even though the former is characterized by a lesser clay-size fraction. This could be explained by the presence of quartz, feldspar, volcanic glass, and/or rock fragments in the sediments of Cores $107-652 A-33 R$ and $-34 R$. The quartz and feldspar/clay mineral ratios (obtained from X-ray diffraction analyses of bulk rock samples) are plotted in Figure 6 as a function of calcite content. The plot shows that quartz and feldspar tend to increase with increasing carbonate content. They are present in larger amounts in Cores 107-652A-33R and -34R than in Cores 107-652A-37R and $-38 R$ and Core 107-652A-24R. This is also confirmed by smear-slide results: quartz content is as high as $20 \%$ in the smear slides from Cores 107-652A-33R and -34R, whereas only quartz traces have been observed in smear slides from Cores $107-652 A-37 R$ and $-38 R$. Because of the observed relationship between carbonate content and grain size we suggest that these minerals are more abundant within coarser sediments. If true, this is evidence that the $\mathrm{SiO}_{2}$ curve alone is not as good an indicator of mineralogical variations as the $\mathrm{CaCO}_{3}$ curve.

The clay mineralogy is based only on core measurements because clay identification on the basis of log data requires a precise estimate of $\mathrm{Al}_{2} \mathrm{O}_{3}$ (see "Processing of Logging Data" section above). The clay assemblage of Hole $652 \mathrm{~A}$ consists of chlorite, illite, smectite, mixed-layers clays (illite-smectite to illitevermiculite and chlorite-smectite to chlorite-vermiculite), kaolinite, and palygorskite (Table 3 and Fig. 7; Fig. 7 also includes some data from Chamley et al., this volume). Chlorite, illite, and smectite are dominant in the studied section. Smectite, which is particularly abundant in the interval above the pebble zone (188-324 mbsf), dramatically decreases below 335 mbsf as mixed-layer clay minerals steadily increase. Smectite eventually disappears around 390 mbsf (Chamley et al., this volume). Kaolinite, on the other hand, remains quite constant through the entire interval. The marked $\mathrm{FeO}^{*}$ increase in the lowermost interval (below the pebble zone, Fig. 5) partly reflects the increase of chlorite and illite (from $29 \%$ to $33 \%$, and from $25 \%$ to $30 \%$ of the clay fraction, respectively). This can be considered consistent with the increase of $\mathrm{K}_{2} \mathrm{O}$ observed around 340 mbsf, potassium being more abundant in the illites (Table 1) than in the 


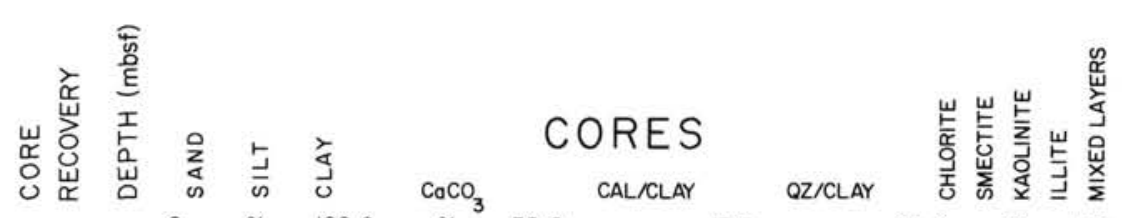
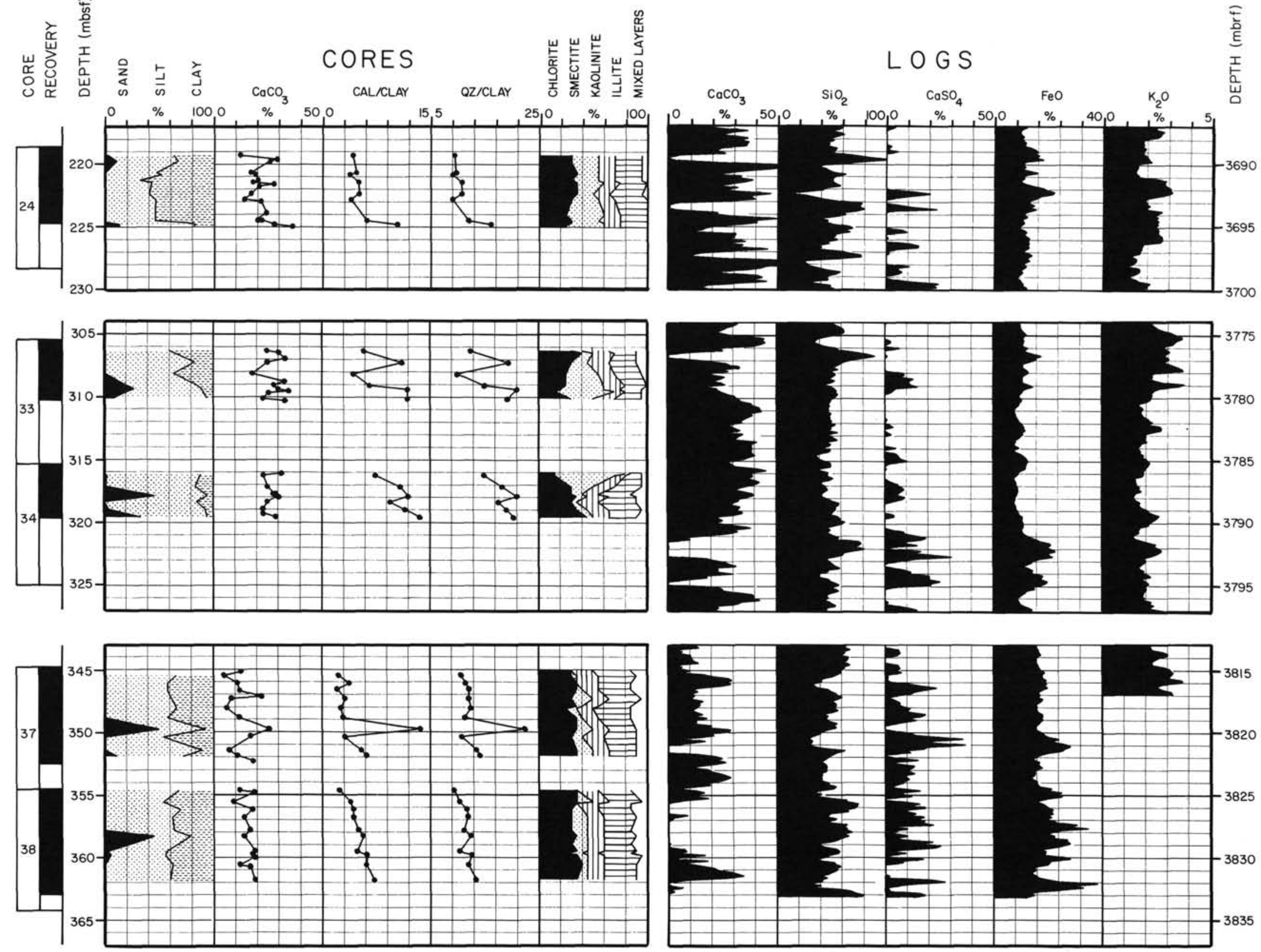

Figure 5. Comparison among estimated oxides and carbonates, $\mathrm{CaCO}_{3}$ (this study, and Kastens, Mascle et al., 1987b), grain-size measurements (this study, and Cita et al., this volume), and XRD bulk and clay mineralogy in selected cores at Hole 652A (this study, and Chamley et al., this volume). 

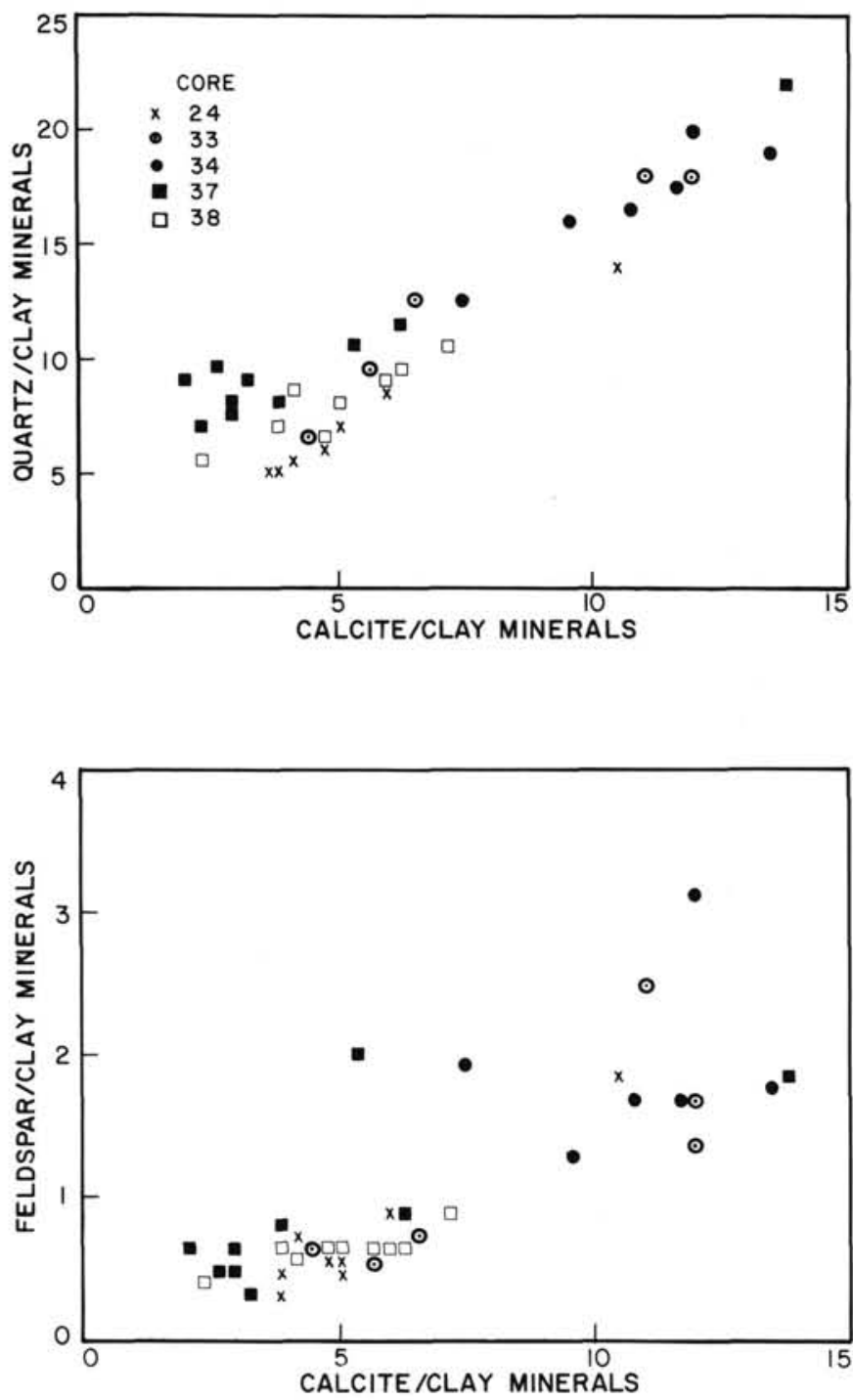

Figure 6. Abundance of quartz and feldspar versus calcite in selected cores from Hole 652A (this study). Quartz and feldspar tend to increase with increasing carbonate content; they are more abundant in the coarse-grained sediments of Cores 107-652A-33R and -34R than in the fine grained sediments of Cores 107-652A-37R and -38R.

other clay minerals. Therefore the $\mathrm{FeO}^{*}$ and $\mathrm{K}_{2} \mathrm{O}$ log-computed curves can be regarded as indicative of variations in iron-rich and potassium-rich clay minerals, respectively.

In conclusion, log-derived results reflect the major mineralogical variations in the three selected intervals, and indicate a relationship between grain size and carbonate content. We can therefore reasonably extrapolate the above observations to the rest of the hole. A synthetic lithologic column, based on a "physical property indicator" (PPI), is presented in Figure 8, along with grain-size analyses and the log-derived $\mathrm{CaCO}_{3}$ curve.

Resistivity, velocity, and apparent porosity are correlated through most of the section (Fig. 2). With the exception of a few intervals in which the resistivity-sonic tool became stuck in the hole, sediments with high apparent porosity are characterized by low velocity and low resistivity values. On the basis of this correlation, we have rescaled each of the curves from 0 to 1 , where 0 and 1 correspond to the minimum and maximum value in the case of the porosity curve, and the opposite in the case of resistivity and velocity. We define the PPI as the average of the rescaled curves. This indicator is intended to enhance the response of geophysical logs to physical-property changes, which are in turn correlated with the grain size and the carbonate content of the sediments. The bimodal distribution shown by the histogram in Figure 9 allows us to discriminate between highly porous sediments (PPI $>0.6$ ) and less porous, more cemented sediments (PPI $>0.5$ ), which correspond to fine-grained $\left(\mathrm{CaCO}_{3}\right.$ poor) and coarse-grained $\left(\mathrm{CaCO}_{3}\right.$-rich) sediments, respectively (shown as black and white intervals in Fig. 8). Intervals with intermediate characteristics fall in the $0.5-0.6$ PPI range.

In the lower part of the logged section (from 240 to 324 mbsf) the dominant lithologies are clayey silt and sand, which gradually decrease uphole. Above 240 mbsf, finer sediments are more abundant up to the Pliocene/Miocene contact. The environment of deposition of this sedimentary sequence has been interpreted as lacustrine (Kastens, Mascle et al., 1987b), on the basis of the complete absence of marine fossils and the presence of few brackish-water ostracodes. Thus the predominance of finer sediments in the upper part of the Messinian sedimentary sequence suggests: (1) an increase through time in the distance from the sediment source (which may have resulted from the widening of the lacustrine basin) or (2) gradual deepening of the lake (as a result of a constant rift-related subsidence rate) and/ or a change in climatic conditions. Of course, none of the above explanations is exclusive. These possible mechanisms are discussed below with regard to the geological and climatic evolution of the area.

\section{DISCUSSION}

\section{Sedimentary Variations}

The continuous nature of the geophysical and geochemical logs recorded at Hole $652 \mathrm{~A}$ allowed us to reconstruct the sedimentary variations in the interval 188-365 mbsf of Hole 652A. Grain size and carbonate content are correlated: fine-grained sediments are less rich in $\mathrm{CaCO}_{3}$ and detrital components (e.g., quartz and feldspars; Figs. 5 and 6), and are characterized by high apparent porosity, low velocity, and low resistivity (Figs. 2 and 8); coarse-grained sediments show opposite features.

The studied section consists of alternations of these two lithofacies (A and B in Fig. 8). These are interpreted as shortterm variations, possibly related to climatic fluctuations (note that these cycles do not correspond to the millimeter-to-centimeter scale, normally and reversely graded layers observed in the cores by Kastens, Mascle et al., 1987b). Periods of semi-arid Mediterranean climate resulted in the formation of caliche and smectitic soils, and the weathering of the rocks on the exposed portions of the crustal blocks. During these restricted periods the water in the adjoining basins became more concentrated because of the reduced inflow and increased evaporation. Deposits composed of clays with reduced amounts of coarser material accumulated, as did evaporites. Sediments containing residual igneous fragments, clay, caliche-generated carbonate grains (barren), cementing gypsum, and reworked clastic sabka gypsum washed into the basin during humid periods. These cyclical climatic changes produced fluctuations in the composition of the basin fill. Unfortunately, the absence of authochtonous fossils in the sedimentary sequence of Hole $652 \mathrm{~A}$ prevents any sort of stratigraphic control and therefore we have no information concerning the timing or accumulation rates for these depositional intervals.

No authigenic gypsum was observed in Hole $652 \mathrm{~A}$ above the pebble zone (Kastens, Mascle et al., 1987b; Cita et al., this volume). The lack of correlation between the log-derived $\mathrm{CaSO}_{4}$ curve and fine-grained versus coarse-grained sediments is a further indication of the clastic nature of gypsum in this interval. 

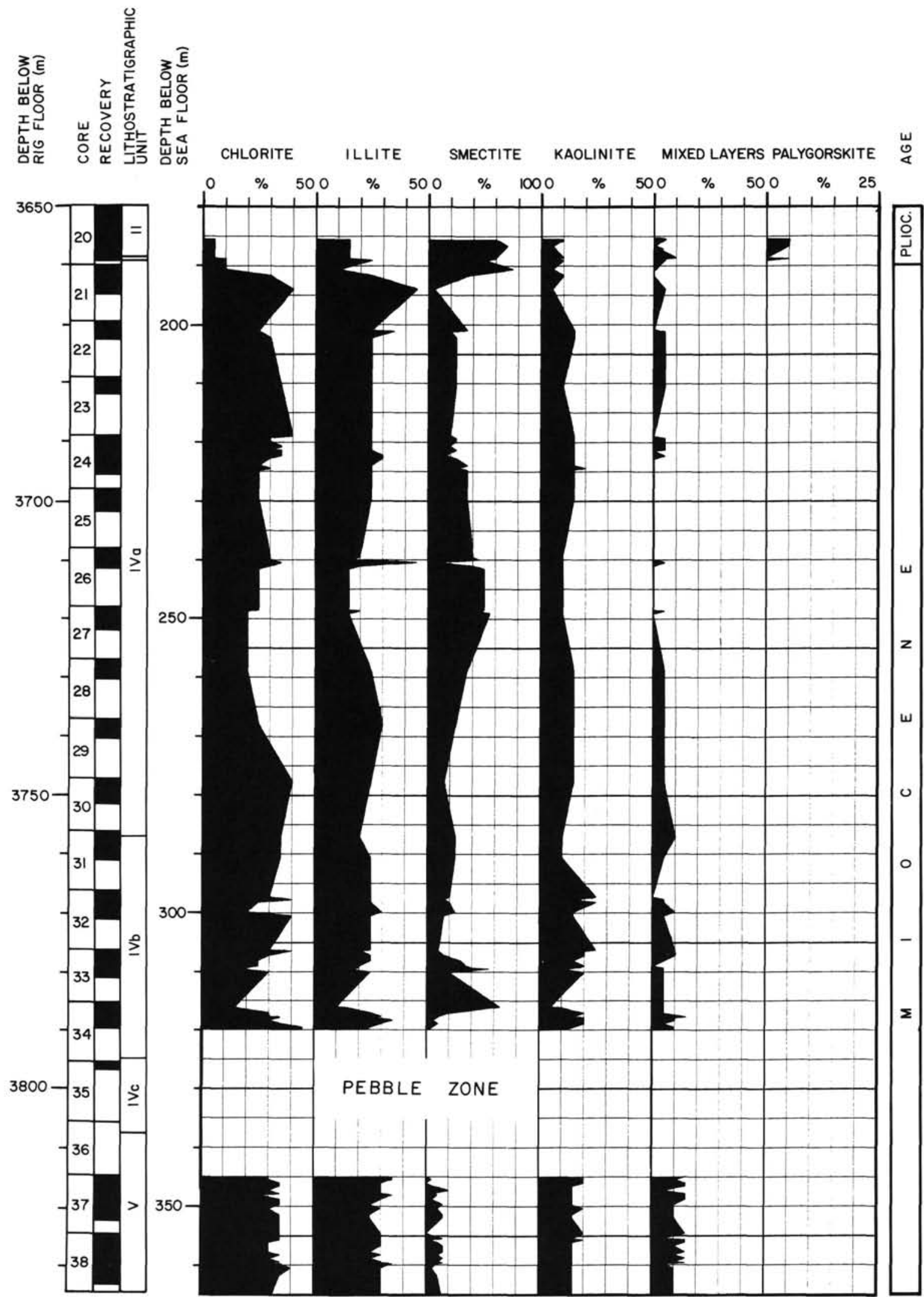

Figure 7. Clay mineralogy of the logged interval from XRD measurements (this study, and Chamley et al., this volume). 


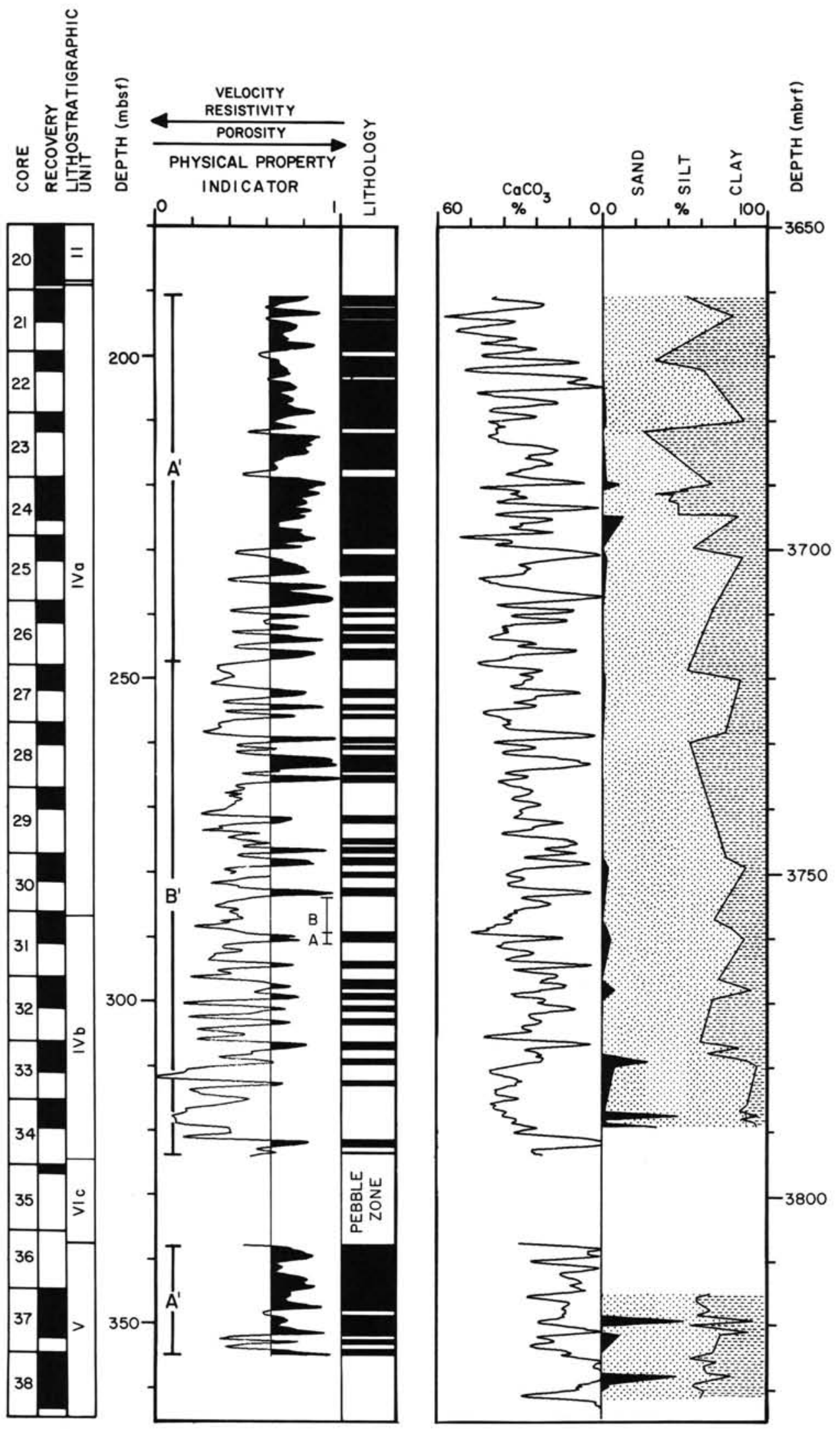

Figure 8. Synthetic lithologic column of the interval 189-355 mbsf compiled using the physical property indicator (PPI) computed from velocity-porosity-resistivity logs (see text for discussion). Arrows indicate increasing porosity, velocity, and resistivity values. A marked decrease of the coarser fraction of the sediments (white) is observed uphole, where the clay fraction (black) becomes dominant. Note the correlation between the PPI and the $\mathrm{CaCO}_{3}$ curve computed from the geochemical logs in the interval 230-365 mbsf. Short-term (A and B) and long-term ( $\mathrm{A}^{\prime}$ and $\left.\mathrm{B}^{\prime}\right)$ lithological variations, and grain-size analyses are shown. 


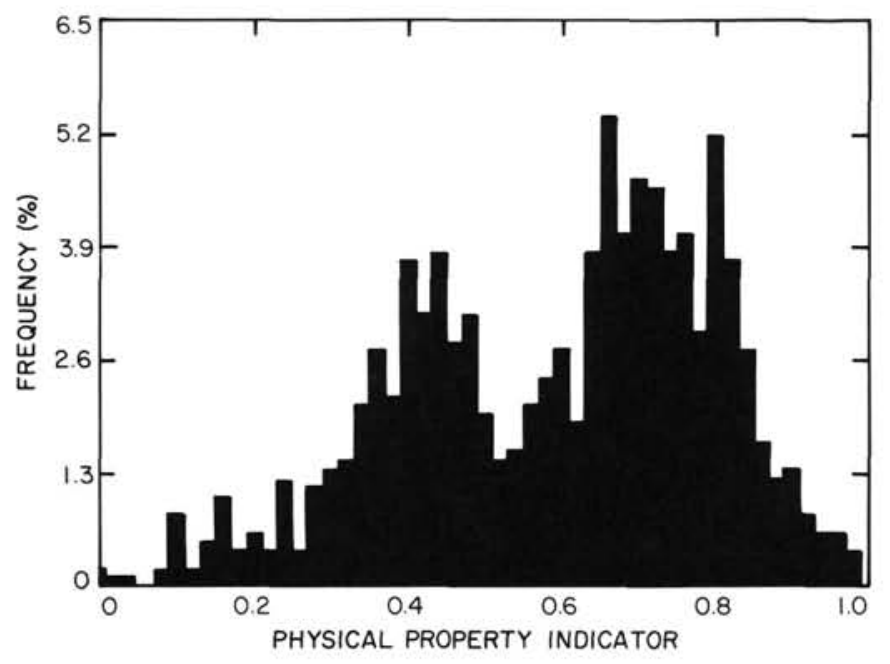

Figure 9. Histogram of the physical property indicator (PPI) at Hole $652 \mathrm{~A}$. The bimodal distribution suggests the presence of fine-grained, highly porous sediments (PPI $<0.5$ ) and coarser-grained (PPI $>0.62$ ) sediments.

Authigenic gypsum generally is abundant within the fine-grained sediments of Hole $652 \mathrm{~A}$, as observed on logs and cores in the 338-365 mbsf interval below the pebble zone.

A much larger-scale variation (A' and B' in Fig. 8) is reflected by grain-size changes, which may indicate a gradual deepening of the (lake) basin in the upper part of the sequence. This is interpreted as the result of rift-related extension (increasing distance of the source) and subsidence (increasing depth). This interpretation is supported by the observation of a similar evolution in the Messinian lacustrine sequences of Tuscany (Lazzarotto, 1967; Lazzarotto and Mazzanti, 1976), which were deposited in a structural setting similar to that of Site 652 (half grabens) and have undergone extensional tectonism since the early Messinian.

We note that below the pebble zone there are fine-grained sediments similar to those observed in the upper part of the sequence. An impassable bridge at 365 mbsf prevented us from logging the entire hole, so we have no log evidence that these sediments represent the top of another upward-fining sequence. Grain-size analyses from the lower part of the hole (Cita et al., this volume), however, seem to support this idea.

The size and the texture of pebbles recovered from the 14-mthick pebble zone that separates the upper and lower sedimentary series (Kastens, Mascle et al., 1987b) suggest two possible types of deposition: (1) a dry stream flood (wadi deposit), similar to present-day occurrences in desertic areas that result after a distant storm causes a huge influx of water into a normally dry stream; (2) a tectonically diverted stream flow that permitted the reworking of older rocks (the pebbles recovered from Hole $652 \mathrm{~A}$ vary from being rounded and smooth to flat and elongated, which suggests that they may have been reworked; Kastens, Mascle et al., 1987b).

\section{Compaction and Diagenesis During Burial}

Ordinarily, compaction and lithification within a sedimentary sequence increase systematically with depth. Under certain conditions, however, early cementation takes place and compaction is considerably reduced. On the eastern Sardinian margin the diagenetic history is even more complex because (1) chemical precipitates (evaporites) that lithified as they formed, without appreciable compaction, are common in some parts of the sequence; (2) the sediments were altered very early in their bur- ial history as a result of dense evaporitic fluids (Kastens, Mascle et al., 1987b) that seeped down into existing deposits and altered their composition and porosity; and (3) a localized high geothermal gradient $\left(14^{\circ} \mathrm{C} / 100 \mathrm{~m}\right.$ today, Kastens, Mascle et al., 1987 b), combined with evaporative pore fluids, caused locally extensive diagenesis.

Unlike Site 654 (upper Sardinian margin), where the Messinian sedimentary sequence has undergone some modest alteration due to (1) and (2) above (Chamley et al., this volume), at Site 652 the geothermal form of alteration (3) has occurred. This has overprinted the original sedimentary history and rendered the interpretation of logging and core data somewhat more difficult.

The decrease in smectite below the pebble zone at $335 \mathrm{mbsf}$ (Fig. 7) and the concomitant increase in chlorite, mixed-layer clays, and illite suggest a diagenetic relationship rather than a depositional one. In general, Messinian smectites originate either in soils formed under semi-arid conditions with strong seasonal precipitation (Paquet, 1969; Chamley, 1983; Chamley et al., 1978), or from the erosion of terrains exposed during the Messinian desiccation of the Mediterranean (Chamley and Robert, 1980). The erosion process, however, seems to be of secondary importance in the case of Site 652. In fact, Chamley et al. (this volume) report that the smectite particles show some features typical of smectites formed in continental soils under arid conditions, thus ruling out the possibility of an evaporitic genesis.

Ordinarily, with burial and increasing pressure the water layers in smectite tend to remain firmly fixed in the lattice, but with a geothermally controlled increase in temperature, such as that measured at Hole $652 \mathrm{~A}$ (presently $14^{\circ} \mathrm{C} / 100 \mathrm{~m}$; Rehault et al., this volume), the smectite becomes unstable and changes to illite (at temperatures of $153^{\circ}-178^{\circ} \mathrm{C}$; Kaiser, 1984; ColtenBradley, 1987) through a mixed-layer-intermediate step (Bodine, 1978). This transformation occurs below the pebble zone where mixed-layer clay minerals and illite show a marked increase.

The high geothermal gradient, coupled with the presence of dense evaporative pore fluids (Kastens, Mascle et al., 1987b) would also cause the formation of dolomite and chlorite. We noted that the amount of kaolinite remains quite constant throughout the studied section. This supports the idea that the change in the clay-mineral association below the pebble zone is related to diagenetic processes rather than to a major change in source terrain. If the change in the clay association (i.e., the increase of illite, mixed-layer clays, and chlorite and a comparable decrease of smectite) were related to tectonism and progressive unroofing and exposure of new terrain, then the kaolinite content also should change with any new exposure.

\section{SUMMARY}

The geochemical and geophysical logs, presented in this paper integrated with various core measurements, provide a continuous picture of the mineralogy of the upper part of Site 652 . This information was unobtainable from core examination alone owing to poor recovery. Core and log analyses over three selected intervals show that grain size and carbonate content are correlated. The extrapolation of this result to the entire section as well as the overall charaxter of a physical-property indicator (obtained from resistivity-porosity-velocity logs) indicate the presence of sedimentary variations at two different scales:

1. Short-term mineralogical variations are represented by fluctuations in the carbonate content and grain size (i.e., coarser sediments are generally characterized by high $\mathrm{CaCO}_{3}$ values along with abundant detrital material). These are interpreted as the result of climatic variations in an arid regime such as that experienced during the Messinian desiccation of the Mediterra- 
nean. In the absence of authochtonous fossils we could not determine the timing or accumulation rates for these depositional intervals.

2. The large-scale variation observed on the logs indicates an overall grain-size change with time (i.e., an upward-fining sequence above the pebble zone). This is interpreted as a gradual deepening of the lacustrine basin, possibly a result of rift-related extension (increasing distance from the source) and subsidence (increasing depth of deposition). Because of the lack of logs in the lower part of the hole we could not verify the presence of a similar pattern below the pebble zone. The results of grain-size analyses conducted in a separate study (Cita et al., this volume), however, do not seem to rule out this possibility.

Clay identification on the basis of the logs is difficult because of the absence of aluminum measurements; therefore we used only X-ray-diffraction analyses. The clay-mineral assemblage of Hole 652A presents some peculiarities not observed in other holes or in land-based clay sequences. The presence of abundant smectites, which generally form in the soils of exposed terrains under arid-to-semiarid conditions, suggests a regional climatic control. This could be confirmed by the shortterm mineralogical variations observed on the logs. Below the conglomeratic interval ( $335 \mathrm{mbsf}$ ) the clay association is characterized by the decrease and eventual disappearance of smectite and the increase in dolomite, chlorite, and mixed-layer clays. This pattern is indicative of active diagenetic processes related to the depth of burial, the chemistry of interstitial waters, and the high geothermal gradient, rather than to a change in the depositional environment.

\section{ACKNOWLEDGMENTS}

We wish to thank the Captain and the crew of the SEDCO/BP 471 (JOIDES Resolution), and the ODP Superintendent of Drilling Operations, D. Huey, for their assistance during the logging operations; particular thanks go to L. Geiser of Schlumberger Offshore Services, who operated the logging tools.

One of the authors (C. B.) wishes to thank R. N. Anderson and A. Malinverno for the useful suggestions during the course of this study. The manuscript has benefitted greatly from the reviews of K. A. Kastens, J. Mascle, F. McCoy, and D. Moos.

\section{REFERENCES}

Bodine, M. W., 1978. Clay-mineral assemblages from drill core of Ochoan evaporites, Eddy County, New Mexico. In Geology and mineral deposits of Ochoan rocks in Delaware basin and adjacent areas, New Mexico Bureau Mines and Mineral Resources, Circular 159:21-31

Chamley, H., 1983. Marine and continental antagonistic influences in Mediterranean Neogene to recent clay sedimentation. Utrecht Micropaleontol. Bull., 30:71-90.

Chamley, H., and Robert, C., 1980. Sedimentation argileuse au Tertiaire superieur dans le domaine mediterraneen. Geol. Mediterr., 7: 25-34.

Chamley, H., Dunoyer de Segonzac, G., and Melieres, F., 1978. Clay minerals in Messinian sediments of the Mediterranean area. In Hsü, K. J., Montadert, L., et al., Init. Repts. DSDP, 42, Pt. 2: Washington (U.S. Govt. Printing Office), 389-397.

Colten-Bradley, V. A., 1987. Role of pressure in smectite dehydrationeffects on geopressure and smectite to illite transformation. $A A P G$ Bull., 71:1414-1427.
Fabbri, A., Gallignani, P., and Zitellini, N., 1981. Geologic evolution of the Peri-Tyrrhenian sedimentary basins. In Wezel, F. C. (Ed.), Sedimentary Basins of Mediterranean Margins: Bologna (Technoprint), 101-126.

Hertzog, R., 1978. Laboratory and field evaluation of an inelastic neutron-scattering and capture gamma-ray spectroscopy tool [paper 7430 presented at the 53rd Annual Technical Conference and Exhibition of the Society of Petroleum Engineers, Houston, TX].

Hertzog, R., and Schweitzer, J., 1986. Aluminum clay tool: aluminum activation logging using the NGT. Schlumberger-Doll Research report.

Hertzog, R., Colson, L., Seeman, B., O'Brien, M., Scott, H., McKeon, D., Wraight, P., Grau, J., Ellis, D., Schweitzer, J., and Herron, M., 1987. Geochemical logging with spectrometry tools [paper 16792 presented at the 62nd Annual Technical Conference and Exhibition of the Society of Petroleum Engineers, Dallas, TX].

Kaiser, W. R., 1984. Predicting reservoir quality and diagenetic history in the Frio Formation (Oligocene) of Texas. In McDonald, D. A., and Surdam, R. C. (Eds.), Clastic Diagenesis. AAPG Mem. 37:195215 .

Kastens, K., Mascle. J., et al., 1987a. Explanatory Notes. In Kastens, K., Mascle, J., et al., Proc. ODP, Init. Repts., 107: College Station, TX (Ocean Drilling Program), 65-88.

1987b. Site 652. In Kastens, K., Mascle, J., et al., Proc. ODP, Init. Repts., 107: College Station, TX (Ocean Drilling Program), 403-597.

Lazzarotto, A., 1967. Geologia della zona compresa fra l'alta valle del fiume Cornia ed il torrente Pavone (province di Pisa e Grosseto). Mem. Soc. Geol. Ital., 6:151-197.

Lazzarotto A., and Mazzanti, R., 1976. Geologia dell'alta Val di Cecina. Boll. Soc. Geol. Ital., 95:1365-1487.

Malinverno, A., Cafiero, M., Ryan, W.B.F., and Cita, M. B., 1981. Distribution of Messinian sediments and erosional surfaces beneath the Tyrrhenian Sea: geodynamic implications. Oceanol. Acta, 4: 489-496.

McKenzie, D. P., 1978. Some remarks on the developments of sedimetary basins. Earth Planet. Sci. Lett., 40:25-32.

Paquet, H., 1969. Evolution geochimique des mineraux argileux dans les alterations et de sols de climats mediterraneens et tropicaux a saisons contrastees. Mem. Serv. Carte Geol. Alsace-Lorraine, 30.

Rehault, J. P., Moussat, E., and Fabbri, A., 1987a. Structural evolution of the Tyrrhenian back-arc basin. Mar. Geol., 74:123-150.

Rehault, J. P., Mascle, J., Fabbri, A., Moussat, E., and Thommeret, M., 1987b. The Tyrrhenian Sea before Leg 107. In Kastens, K., Mascle. J., et al., Proc. ODP, Init. Repts., 107: College Station, TX (Ocean Drilling Program), 9-35.

Schlumberger, 1972. Log Interpretation: Principles (Vol. 1): New York (Schlumberger Ltd).

Steinmetz, L., Ferrucci, F., Hirn, A., Morelli, C., and Nicolich, R., 1983. A $550-\mathrm{km}$ Moho traverse in the Tyrrhenian Sea from O.B.S. recorded $\mathrm{P}_{\mathrm{n}}$ waves. Geophys. Res. Lett., 10:428-431.

Trincardi, F., and Zitellini, N., 1987. The rifting of the Tyrrhenian Basin. Geo-Mar. Lett., 7:1-6.

Westaway, P., Hertzog, R., and Plasek, R. E., 1980. The gamma spectrometer tool inelastic and capture gamma-ray spectroscopy for reservoir analysis [paper 9461 presented at the 55th Annual Technical Conference and Exhibition of the Society of Petroleum Engineers, Dallas, TX].

Date of initial receipt: 12 February 1988

Date of acceptance: 13 January 1989

MS 107B-178 